\title{
Pengaruh Kepemilikan Asing, Kepemilikan Institusional dan Leverage terhadap Pengungkapan Corporate Social Responsibility
}

\author{
Ni Putu Tista Paradiva Yani ${ }^{1}$ \\ Fakultas Ekonomi dan Bisnis \\ Universitas Udayana, Indonesia \\ Email: tistaparadiva@gmail.com
}

\author{
I Dewa Gede Dharma Suputra2 \\ Fakultas Ekonomi dan Bisnis \\ Universitas Udayana, Indonesia
}

\begin{abstract}
ABSTRAK
Tujuan dari penelitian ini untuk mengetahui pengaruh kepemilikan asing, kepemilikan institusional, dan leverage terhadap pengungkapan corporate social responsibility. Teori yang digunakan yaitu teori stakeholder. Penelitian ini dilakukan di Bursa Efek Indonesia (BEI) pada perusahaan pertambangan periode tahun 2016-2018. Teknik anaisis data yang digunakan adalah analisis regresi linier berganda. Metoda penentuan sampel nonprobability sampling dengan teknik purposive sampling. Jumlah sampel sebanyak 51 dari 17 perusahaan dengan periode waktu amatan tiga tahun. Hasil analisis menunjukkan bahwa, kepemilikan asing kepemilikan institusional, berpengaruh terhadap pengungkapan corporate social responsibility, sedangkan leverage tidak berpengaruh terhadap pengungkapan corporate social responsibility.
\end{abstract}

Kata Kunci: Corporate Social Responsibility; Kepemilikan Asing; Kepemilikan Institusional; dan Leverage.

\section{Effects of Foreign Ownership, Institutional Ownership, and Leverage on Corporate Social Responsibility Disclosures}

\section{ABSTRACT}

The purpose of this study was to determine the effect of foreign ownership, institutional ownership, and leverage on corporate social responsibility disclosure. The theory used is stakeholder theory. This research was conducted at the Indonesia Stock Exchange (IDX) in the mining company for the period of 2016-2018. Data analysis technique used is multiple linear regression analysis. The method of determining the sample non probability sampling with purposive sampling technique. The number of samples was 51 of 17 companies with a threeyear observation period. The analysis shows that foreign ownership, ownership, institutional influence on the disclosure of corporate social responsibility, while leverage does not affect the disclosure of corporate social responsibility.

Keywords: $\quad$ Corporate Social Responsibility; Foreign Ownership; Institutional Ownership; and Leverage.

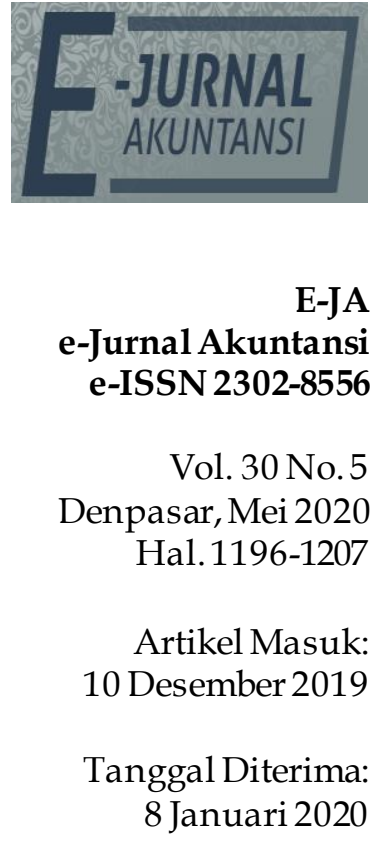




\section{PENDAHULUAN}

Corporate Social Responsibility (CSR) adalah isu yang sudah berkembang dan sangat penting bagi perusahaan nasional maupun perusahaan internasional. Fonemena ini terjadi karena semakin berkembangnya tren tentang praktik corporate social responsibility dalam bisnis. Corporate Social Responsibility (CSR) harus dijadikan strategi bisnis oleh perusahaan-perusahaanl yangl inginl tetap; berkelanjutan danl memiliki; keunggulan; kompetitif (Dewi \& Suaryana, 2015).

Pengungkapan CSR merupakan bagian dari akuntansi pertanggungjawaban sosial yang mengkomunikasikan informasi sosial kepada para stakeholder (Widyastari, 2018). Informasi mengenai pertanggungjawaban sosial, akan meningkatkan image perusahaan dan meningkatkan penjualan, (Hackston, 2009). Global Reporting Initiative (GRI) merupakan standar untuk pembuatan laporan keberlanjutan; atau sustainability; report yang dijadikan pedoman saat ini di Indonesia. Perusahaan pertambangan menurut Wahana Lingkungan Hidup Indonesia (WALHI) merupakan perusahaan yang paling berkontribusi besar terhadap kerusakan alam yang terjadi di kawasan Indonesia (Brata, 2014). Beberapa fenomena yang menunjukkan bahwa perusahaanperusahaan di Indonesia belum sepenuhnya menerapkan CSR. Adapun beberapa fenomenal kegagalan CSR yang muncul di Indonesia yaitu salah satunya pada kasus yang terjadi pada PT Freeport Indonesia. PT Freeport merupakan anak perusahaan Freeport-McMoran Copper \& Gold Inc. yaitu perusahaan tambang internasional utama dengan pusat di Phoenix, Arizona, Amerika Serikat. PT Freeport telah mencemari lingkungan akibat limbah sisa pertambangan, air sungai, pengendapan sedimen, kandungan limbah logam yang berbahaya, serta penggunaan hutan lindung berdasarkan data yang dirilis oleh LSM Wahana Lingkungan Hidup (Walhi) serta Program Kinerja Pengelolaan Lingkungan Hidup. PT Freeport membuang tailing dengan kategori limbah B3 (bahan, beracun, berbahaya) melalui sungai Ajkwa. Limbah ini telah mencapai pesisir laut Arafura. Tailing yang dibuang PT Freeport ke sungai Ajkwa melampaui baku mutu total suspend solid (TSS) yang diperbolehkan menurut hukum Indonesia. Limbah tailing PT Freeport juga telah mencemari perairan di muara sungai Ajkwa dan mengontaminasi sejumlah besar jenis mahluk hidup serta mengancam perairan dengan air asam tambang berjumlah besar.

PT Lapindo Brantas yang merupakan anak perusahaan PT Energi Mega Persada Tbk, yang 60 persen sahamnya dimiliki oleh Bakrie Group juga telah mencemari lingkungan akibat semburan lumpur panas yang mulai terjadi sejak tanggal 28 Mei 2006 di kawasan Porong, Sidoarjo. Insiden ini terjadi akibat pengeboran gas yang dilakukan loleh PT Medicitra Nusantara sebagai sub kontraktor dari PT Lapindo Brantas sedalam $32 \mathrm{~km}$ yang menyemburkan gas bercampur lumpur yang ditengarai oleh beberapa pihak sebagai lumpur gunung berapi. Semburan lumpur yang akhirnya membentuk kubangan lumpur panas ini telah memporak-porandakan sumber-sumber kehidupan warga setempat dan sekitarnya.

Menurut (Giuliani, 2016) permasalahan-permasalahan sosial yang dihadapi oleh perusahaan di Indonesia juga terjadi karena lemahnya penegakan peraturan tentang Corporate Social Responsibility (CSR), misalnya tentang aturan ketenagakerjaan pencemaran lingkungan, perimbangan bagi hasil suatu industry 
dalam era otonomi daerah. Faktor yang berpengaruh terhadap pengungkapan corporate social responsibility yaitu, kepemilikan asing kepemilikan institusional dan leverage.

Kepemilikan asing dalam perusahaan merupakan pihak yang dianggap concern terhadap pengungkapan pertanggungjawaban sosial perusahaan, hal ini disebabkan kepemilikan asing memiliki tingkat untuk mengawasi manajeman yang tinggi dalam mengawasi perusahaan untuk melakukan kegiatan/aktivitas sosial. Perusahaan (Maulida, 2013). Salah satu media yang dijadikan perusahaan untuk mendapatkan. Legitimasi dari masyarakat di lingkungan perusahaan adalah dengan melakukan pengungkapan CSR.

Kepemilikan institusional merupakan kepemilikan saham perusahaan. yang mayoritas dimiliki oleh institusi ataulembaga (perusahaan asuransi, bank, perusahaan investasi, asset management dan kepemilikan institusi lain). Adanya kepemilikan oleh institusional akan mendorong pengawasan yang lebih optimal. Leverage merupakan rasio yang menunjukkan. Bagaimana perusahaan mampu untuk mengelola utangnya dalam rangka memperoleh keuntungan dan juga mampu untuk melunasi kembali utangnya (Surmadewi \& Suputra, 2019).

Berdasarkan latar belakang tersebut tujuan dilakukannya penelitian ini yaitu : untuk mengetahui apakah kepemilikan asing berpengaruh pada pengungkapan corporate social responsibility. Untuk mengetahui apakah kepemilikan institusional berpengaruh pada pengungkapan corporate social responsibility. Untuk mengetahui apakah leverage berpengaruh pada pengungkapan corporate social responsibility.

Hasil penelitian ini dapat memberikan pengetahuan dan menambah wawasan serta informasi yang berkaitan dengan akuntansi khususnya teori stakeholder yang berkaitan dengan kepemilikan asing kepemilikan institusional dan leverage terhadap pengungkapan corporate social responsibility. Dapat memberikan informasi kepada perusahaan pertambangan sebagai pertimbangan bagi para manajemen perusahaan dalam membuat dan mengambil kebijakan perusahaan yang terkait dengan pengungkapan corporate social responsibility.

Teori stakeholder mengatakan bahwa perusahaan bukanlah entitas yang hanya beroperasi untuk kepentingan sendiri namun harus memberikan manfaat bagi stakeholder-nya seperti pemegang saham, kreditur, konsumen, pemasok, pemerintah, masyarakat dan pihak lain (Ghozali \& Chariri, 2007:32). Teori stakeholder memberikan syarat bahwa perusahaan harus memberi perhatian kepada stakeholder karena stakeholder dapat memberikan pengaruh dan dipengaruhi oleh perusahaan berkaitan dengan aktivitas dan kebijakan yang dilaksanakan (Dwipayadnya et al., 2015). Pengungkapan CSR penting karena para stakeholder perlu mengetahui dan mengevaluasi sejauh mana. perusahaan melaksanakan peranannya sesuai dengan keinginan stakeholder, sehingga menuntut adanya akuntabilitas perusahaan atas kegiatan CSR yang telah dilakukannya (Riswari, 2012). Pengungkapan sosial dianggap sebagai bagian dari dialog antara perusahaan dengan para stakeholder. Stakeholder theory umumnya berkaitan dengan cara-cara yang digunakan perusahaan untuk memanage stakeholder-nya (Gray, et al., 1997).

Annual report digunakan sebagai media pengungkapan CSR dengan tujuan agar stakeholder dapat dengan mudah mengetahui bagaimana kinerja 
perusahaan yang dijalankannya. Pelaporan mengenai kebijakan ekonomi, lingkungan dan sosial, pengaruh dan kinerja organisasi, dan produknya didalam konteks pembangunan berklanjutan (sustainable development) diungkap dalam sustainability report (Dewi \& Suputra, 2019). Pengungkapan CSR diukur menggunakan Corporate Social Responsibility Disclosure Index (CSRDI). Kemudia CSRDI diukur menggunakan standar GRI. Standar GRI-G4 indikator kinerjanya dibagi menjadi 3 komponen utama yaitu ekonomi lingkungan hidup dan sosial. Pengungkapan CSR dalam penelitian ini mengacu pada standar GRI-G4 (Global Reporting Initiative Generation), karena lebih memfokuskan pada standar pengungkapan berbagai kinerja ekonomi sosial dan lingkungan perusahaan dengan tujuan untuk meningkatkan kualitas dan pemanfaatan sustainanbility reporting.

Kepemilikan saham asing merupakan salah satu stakeholder perusahaan yang menjadi sasaran dari pengungkapan CSR. Salah satu media yang dipilih untuk menunjukkan kepedulian perusahaan pada masyarakat yaitu pengungkapan CSR perusahaan. Apabila perusahaan memiliki kontrak dengan foreign stakeholders, maka perusahaan akan lebih didukung dalam melakukan pengungkapan tanggung jawab sosial. Teori stakeholder mengatakan kepemilikan asing yang tinggi dalam sebuah perusahaan membuat manajer berusaha untuk melakukan pengungkapan CSR yang tinggi pula karena kepemilikan asing dalam perusahaan merupakan pihak yang dianggap concern terhadap pengungkapan pertanggungjawaban sosial perusahaan. Berdasarkan asumsi bahwa negara-negara asing cenderung lebih perhatian terhadap aktivitas serta pengungkapan Corporatel Social Responsibility (CSR). Hasil penelitian yang dilakukan oleh Prasetyo (2015), Ikmal (2014), Martínez (2016), Tan (2016), Dewi \& Suaryana (2015) menyatakan bahwa kepemilikan asing terbukti berpengaruh terhadap pengungkapan CSR. Berdasarkan uraian, maka dapat dirumuskan hipotesisl sebagai berikut:

$\mathrm{H}_{1}$ : Kepemilikan asing berpengaruh positif pada pengungkapan Corporate Social Responsibility (CSR).

Tingkat kepemilikan institusional yang tinggi akan menimbulkan usaha pengawasan yang lebih besar oleh pihak investor institusional sehingga dapat menghalangi perilaku opportunistic manajer (Nurkhin, 2009). Pengawasan pada kebijakan manajemen dapat lebih kuat dilakukan oleh pihak institusional dibandingkan pemegang saham lainnya, sehingga pihak institusional dapat menuntut manajemen untuk mengungkapkan kegiatan perusahaan. Jika dilihat dari teori stakeholder, semakin besar kepemilikan institusional dalam perusahaan maka tekanan terhadap manajemen perusahaan untuk mengungkapkan tanggungjawab sosial pun semakin besar. Hasil penelitian sebelumnya yang dilakukan oleh Fajrina (2014), Haniffa (2005), Sanjaya (2012), Soliman et al. (2012), Mathews (2014), Edisonn (2017) yang mendapatkan hasil bahwa faktor kepemilikan institusional memiliki pengaruh terhadap pengungkapan corporate social responsibility. Berdasarkan teori dan hasil penelitian sebelumnya, maka hipotesis yang diajukan dalam penelitian ini adalah :

$\mathrm{H}_{2}$ : Kepemilikan institusional berpengaruh positif pada pengungkapan Corporate Social Responsibility (CSR). 
Leverage merupakan rasio yang menunjukkan sejauh mana perusahaan dibiayai dengan utang. Berdasarkan teori stakeholder, tingkat leverage; perusahaan yang tinggi mengakibatkan tingkat resiko tak tertagihnya utang menjadi tinggi pula sehingga kreditor melakukan pengawasan yang ketat terhadap aktivitas perusahaan (Belkaoui \& Karpik, 1989). Perusahaan yang mempunyai tingkat leverage yang tinggi berarti sangat bergantung pada pinjaman kreditor untuk membiayai aktiva perusahaan (Brigham \& Houston, 2006). Tingginya leverage untuk membiayai aktiva perusahaan, dimana hal ini akan mempengaruhi pengungkapan CSR yang dilakukan perusahaan karena utang perusahaan berasal dari kreditor. Intensitasl pengungkapan CSR akan meningkat seiring dengan meningkatnya leverage. Hasil penelitian sebelumnya yang dilakukan oleh Oktariani \& Mimba (2014), Prihatiningtias (2014), Purba (2015), Yanti \& Budiasih (2016) serta Indraswari \& Mimba, (2017) yang mendapatkan hasil bahwa faktor leverage memiliki pengaruh positif pada pengungkapan CSR.

$\mathrm{H}_{3}$ : Leverage berpengaruh positif pada pengungkapan Corporate Social Responsibility (CSR).

\section{METODE PENELITIAN}

Penelitian ini menggunakan seluruh perusahaan pertambangan yang terdaftar di Bursa Efek Indonesia (BEI) periode 2016-2018 sebagai populasi. Jumlah populasi dalam penelitian ini adalah 49 perusahaan pertambangan yang terdaftar di Bursa Efek Indonesia (BEI). Pengambilan sampel dipilih menggunakan metoda nonprobability sampling dengan teknik purposive sampling. Adapun kriteria pemilihan sampel dalam penelitian ini yaitu sebagai berikut : 1) Perusahaan pertambangan yang mempublikasikan laporan tahunan (annual report) secara berturut-turut selama tahun 2016-2018 yang dapatl diaksesl melaluil website lwww.idx.co.id. 2) Perusahaan pertambangan yang, mengungkapkan data lengkap mengenai variabel yang berkaitan dengan penelitian yaitu kepemilikan asing kepemilikan institusional leverage dan Pengungkapan Corporate Social Responsibility (CSR).

Sumber data yang digunakan dalam penelitian ini adalah data sekunder berupa data-data keuangan seperti kepemilikan asing, kepemilikan institusional, leverage, dan item pengungkapan CSR yang dilaporkan pada annual report perusahaan pertambangan yang telah dipublikasikan di BEI tahun 2016 -2018. Statistical Product and Service Solutions (SPSS) merupakan aplikasi yang digunakan untuk mengolah data, sehingga hasil dari hipotesis yang telah dibuat dapat diketahui. Teknik analisis data yang digunakan dalam penelitian ini adalah teknik analisis regresi linear berganda.

Lokasi penelitian ini dilakukan pada perusahaan pertambangan yang terdaftar di Bursa Efek Indonesia (BEI) yang diakses melalui situs resmi BEI yaitu www.idx.co.id. Objek dalam penelitian ini adalah pengungkapan Corporate Social Responsibility (CSR) (Y) pada perusahaan pertambangan tahun 2016 - 2018 dengan variabel yang diduga memengaruhi yaitu kepemilikan asing, kepemilikan institusiona dan leverage tahun 2016-2018. Perusahaan pertambangan dipilih sebagai objek penelitian ini karena pada umumnya perusahaan pertambangan merupakan perusahaan yang sering mendapatkan 
sorotan dari masyarakat, dikarenakan operasi perusahaan pertambangan sangat erat hubungannya dengan lingkungan dan masyarakat sekitar.

Teknik analisis data yang digunakan dalam penelitian ini, yaitu dengan analisis regresi linier berganda yang digunakan untuk menguji pengaruh kepemilikan asing kepemilikan institusional dan leverage terhadapi pengungkapan CSR. Model regresi linear berganda untuk variabel penelitian disajikan sebagai berikut.

$Y=\alpha+\beta_{1} . X_{11}+\beta_{2} . X_{21}+\beta_{3} . X_{31}+\beta_{4} . X_{41}+\varepsilon$

Keterangan:

$\mathrm{Y}=$ Pengungkapan Corporate Social Responsibility (CSR)

$\alpha=$ Konstanta;

$\beta \mathrm{i}=$ Koefisien Regresi

X1 = Kepemilikan Asing

$\mathrm{X} 2$ = Kepemilikan Institusional

$\mathrm{X} 3=$ Leverage

$(\varepsilon)=$ Standar eror

\section{HASIL DAN PEMBAHASAN}

Hasil dari seleksi sampel dengan menggunakan metoda nonprobability sampling dengan teknik purposive sampling diperoleh perusahaan sebagai sampel penelitian tahun pengamatan periode 2016 sampai dengan tahun 2018 adalah sebanyak 17 perusahaan pertambangan. Jadi jumlah observasi yang memenuhi kriteria sampel selama tahun pengamatan periode 2016 sampai dengan tahun 2018 adalah 51 observasi.

Analisis statistik deskriptif digunakan untuk memberikan informasi umum tentang karakteristik variabel penelitian yang berupa nilai tertinggi nilai terendah, rata-rata, dan standar devisiasi dari variabel kepemilikan asing, kepemilikan institusional, leverage, dan pengungkapan Corporate Social Responsibility (CSR). Hasil statistik deskriptif dapat dilihat pada Tabel 1. berikut. Tabel 1. Statistik Deskriptif

\begin{tabular}{lrllll}
\hline & $\mathrm{N}$ & Minimum & Maximum & Mean & $\begin{array}{l}\text { Std. } \\
\text { Deviation }\end{array}$ \\
\hline Kepemilikan Asing & 51 & .01962 & .88400 & .2952749 & .27044978 \\
Kepemilikan Institusional51 & .07483 & .92606 & .5005892 & .28103963 \\
Leverage & 51 & .16300 & 5.97623 & .9161388 & 1.10933894 \\
Pengungkapan CSR & 51 & .07692 & .95604 & .2755871 & .15805604 \\
Validl Nl 1(listwise) & 51 & & & & \\
\hline
\end{tabular}

Sumber: Data Penelitian, 2019

Berdasarkan hasil uji statistik deskriptif masing-masing variabel pada Tabel 1, maka dapat dijelaskan sebagai berikut, nilai kepemilikan asing $\left(\mathrm{X}_{1}\right)$ paling rendah (minimum) adalah sebesar 1,96 persen dan kepemilikan asing yang paling tinggi (maksimum) adalah sebesar 88,4 persen. Kepemilikan asing memiliki nilai rata-rata sebesar 29,52 persen, dengan nilai standar deviasi sebesar 27,04 persen. Hal tersebut menunjukkan makna bahwa sebaran kepemilikan asing pada 17 perusahaan pertambangan yang diteliti selama periode 2016-2018 sudah merata atau perbedaan data satu dengan data yang lainnya tidak tergolong tinggi. 
Nilai kepemilikan institusional $\left(\mathrm{X}_{2}\right)$ paling rendah (minimum) adalah sebesar 7,48 persen dan kepemilikan institusional yang paling tinggi (maksimum) adalah sebesar 92,60 persen. Kepemilikan institusional memiliki nilai rata-rata sebesar 50,05 persen dengan nilai standar deviasi sebesar 28,1 persen. Hal tersebut berarti bahwa sebaran nilai kepemilikan institusiona pada 17 perusahaan pertambangan yang diteliti selama periode 2016-2018 sudah merata atau perbedaan data satu dengan data yang lainnya tidak tergolong tinggi.

Nilail leverage $\left(X_{3}\right)$ paling rendah (minimum) adalah sebesar 16,3 persen dan leverage yang paling tinggi (maksimum) adalah sebesar 597,6 persen. Leverage memiliki nilai rata-rata sebesar 91,6 persen, dengan nilai standar deviasi sebesar 110,9 persen. Hal tersebut menunjukkan makna bahwa sebaran leverage pada 17 perusahaan pertambangan yang diteliti selama periode 2016-2018 belum merata atau perbedaan data satu dengan data yang lainnya tergolong tinggi.

Nilail pengungkapan Corporate Social Responsibility (CSR) (Y) paling rendah (minimum) adalah sebesar 7,69 persen dan pengungkapan Corporate Social Responsibility (CSR) yang paling tinggi (maksimum) adalah sebesar 95,60 persen. Pengungkapan Corporate Social Responsibility (CSR) memiliki nilai ratarata sebesar 27,55 persen, dengan nilai standar deviasi sebesar 15,80 persen. Hal tersebut menunjukkan makna bahwa sebaran pengungkapan Corporate Social Responsibility (CSR) pada 17 perusahaan pertambangan yang diteliti selama. periode 2016-2018 sudah merata atau perbedaan data satu dengan data yang lainnya tidak tergolong tinggi.

Analisis regresi linear berganda digunakan untuk menganalisis pengaruh kepemilikan asing, kepemilikan institusional, dan leverage terhadap pengungkapan Corporate Social Responsibility (CSR). Hasil analisis regresi linear berganda dapat dilihat pada Tabel 2 berikut.

\section{Tabel 2. Hasil Analisis Regresi Linear Berganda}

\begin{tabular}{llllll}
\hline Model & \multicolumn{2}{l}{$\begin{array}{l}\text { Unstandardized } \\
\text { Coefficients }\end{array}$} & \multicolumn{2}{l}{$\begin{array}{l}\text { Standardized } \\
\text { Coefficients }\end{array}$} & \\
\cline { 2 - 5 } & $\mathrm{B}$ & Std. Error & Beta & $\mathrm{t}$ & Sig. \\
\hline 1. (Constant) & -.099 & .089 & & -1.119 & .269 \\
Kepemilikan Asing & .422 & .082 & .585 & 5.141 & .000 \\
Kepemilikan Institusional & .344 & .092 & .430 & 3.726 & .001 \\
Leverage & .114 & .075 & .170 & 1.508 & .138 \\
\hline
\end{tabular}

Sumber: Data Penelitian, 2019

Dari hasil analisis regresi linear berganda pada Tabel 2. tersebut, maka dapat dibuat persamaan sebagai berikut:

$$
Y=-0,099+0,422 X_{1}+0,344 X_{2}+0,114 X_{3}
$$

Nilail konstanta sebesar $-0,099$, jika nilai kepemilikan asing $\left(X_{1}\right)$, kepemilikan intitusional $\left(X_{2}\right)$, dan leverage $\left(X_{3}\right)$, sama dengan nol, maka nilai pengungkapan Corporate Social Responsibility (CSR) (Y) tidak meningkat atau cenderung bernilai negatif sebesar $-9,9$ persen. $\beta_{11}=0,422$, jika nilai kepemilikan asing $\left(\mathrm{X}_{1}\right)$ bertambah 11 persen, maka nilai dari pengungkapan Corporate Social Responsibility (CSR) (Y) akan cenderung mengalami peningkatan sebesar 42,2 persen dengan asumsi variabel bebas lainnya konstan. $\beta_{2,}=10,344$, jika; lnilai kepemilikan institusional $\left(X_{2}\right)$ bertambah 11 persen, maka nilai dari 
pengungkapan Corporate Social Responsibility (CSR) (Y) akan cenderung mengalami peningkatan sebesar 34,4 persen dengan asumsi variabel bebas lainnya konstan. $\beta_{3}=0,114$, jika nilai leverage $\left(X_{3}\right)$ bertambah 11 persen, maka nilai dari pengugkapan Corporate Social Responsibility (CSR) (Y) akan cenderung mengalami peningkatan sebesar 11,4 persen dengan asumsi variabel bebas lainnya konstan.

Uji hipotesis bertujuan untuk menguji seberapa besar pengaruh satu variabel independen dalam menerangkan variasi variabel dependen. Hasil uji hipotesis dapat dilihat pada Tabel 3 berikut.

Tabel 3. Hasil Uji Hipotesis (Uji t)

\begin{tabular}{llllll}
\hline Variabel & $\begin{array}{l}\text { Koefisien } \\
\text { Regresi } \\
(\mathrm{B})\end{array}$ & $\begin{array}{l}\text { Nilai } \\
\text { hitung }\end{array}$ & $\mathrm{t}$ & Sig. & Simpulan \\
\hline Kepemilikan asing $\left(\mathrm{X}_{1}\right)$ & 0,422 & 5,141 & 0,000 & Signifikan \\
Kepemilikan institusional $\left(\mathrm{X}_{2}\right)$ & 0,344 & 3,726 & 0,001 & Signifikan \\
Leverage $\left(\mathrm{X}_{3}\right)$ & 0,114 & 1,508 & 0,138 & $\begin{array}{l}\text { Tidak } \\
\text { Signifikan }\end{array}$ \\
\hline
\end{tabular}

Sumber: Data Penelitian, 2019

Berdasarkan hasil uji t pada Tabel 3. maka dapat dijelaskan hubungan antar variabel sebagai berikut.

Hasil perhitungan ujii $\mathrm{t}$ pada Tabel 3. tersebut menunjukkan nilai koefisien regresi $X_{1}$ atau kepemilikan asing adalah sebesar 0,422 yaitu bernilai positif dengan tingkat signifikansi sebesar 0,0001 kurang dari 0,05. Hal ini menunjukkan bahwa kepemilikan asing berpengaruh positif terhadap pengungkapan Corporate Social Responsibility (CSR). Maka hipotesis yang menyatakan bahwa kepemilikan asing berpengaruh positif terhadap pengungkapan Corporate Social Responsibility (CSR) diterima.

Hasil perhitungan uji $t$ pada Tabel 3. tersebut menunjukkan nilai koefisien regresi $X_{2}$ atau kepemilikan institusional adalah sebesar 0,344 yaitu bernilai positif dengan tingkat signifikansi sebesar 0,001 kurang dari 0,05. Hal ini menunjukkan bahwa kepemilikan institusional berpengaruh positif terhadap pengungkapan Corporate Social Responsibility (CSR). Maka hipotesis yang menyatakan bahwa kepemilikan institusional berpengaruh positif terhadap pengungkapan Corporate Social Responsibility (CSR) diterima.

Hasil perhitungan uji $\mathrm{t}$ pada Tabel 3 . tersebut menunjukkan nilai koefisien regresi $X_{3}$ atau leverage adalah sebesar 0,114 dengan tingkat signifikansi sebesar 0,138 lebih besar dari 0,05. Hal ini menunjukkan bahwa leverage tidak berpengaruh terhadap pengungkapan Corporate Social Responsibility (CSR). Maka hipotesis yang menyatakan bahwa leverage berpengaruh positif terhadap pengungkapan Corporate Social Responsibility (CSR) ditolak.

Berdasarkan hasil analisis yang telah dibahas sebelumnya menunjukkan bahwa kepemilikan asing berpengaruh positif terhadap pengungkapan Corporate Social Responsibility (CSR). Hal ini berarti bahwa semakin tinggi tingkat kepemilikan asing pada perusahaan, maka upaya pengungkapan CSR akan cenderung semakin meningkat. Hal tersebut dikarenakan tingginya kepemilikan asing membuat manajemen akan memiliki dorongan yang semakin besar untuk melakukan pengungkapan CSR. Hasil ini sesuai dengan teori stakeholder, yang 
menyatakan bahwa kepemilikan asing yang tinggi dalam sebuah perusahaan membuat manajer berusaha untuk melakukan pengungkapan CSR yang tinggi pula karena kepemilikan asing dalam perusahaan merupakan pihak yang dianggap concern terhadap pengungkapan pertanggungjawaban sosial perusahaan. Berdasarkan asumsi bahwa negara-negara asing cenderung lebih perhatian terhadap aktivitas serta pengungkapan Corporate Social Responsibility (CSR).

Berdasarkan hasil analisis yang telah dibahas sebelumnya menunjukkan bahwa kepemilikan institusional berpengaruh positif terhadap pengungkapan Corporate Social Responsibility (CSR). Hal ini berarti bahwa semakin tinggi tingkat kepemilikan institusional pada perusahaan, maka upaya pengungkapan CSR akan cenderung semakin meningkat. Hal tersebut dikarenakan tingginya tingkat kepemilikan institusional akan menimbulkan usaha pengawasan yang lebih besar oleh pihak investor institusional, sehingga pihak institusional dapat melakukan pengawasan terhadap kebijakan manajemen secara lebih kuat. Hasil ini sesuai dengan teori stakeholder, yang menyatakan bahwa semakin besar kepemilikan institusional dalam perusahaan maka tekanan terhadap manajemen perusahaan untuk mengungkapkan tanggungjawab sosial semakin besar.

Berdasarkan hasil analisis yang telah dibahas sebelumnya menunjukkan bahwa leverage tidak berpengaruh terhadap pengungkapan Corporate Social Responsibility (CSR). Hal ini berarti bahwa tinggi rendahnya leverage tidak mempengaruhi pengungkapan Corporate Social Responsibility (CSR) perusahaan. Informasi ini memberikan gambaran bahwa hubungan yang sudah terjalin baik denganl debtholders dan kinerja perusahaan yang baik bisa membuat debtholders tidak terlalu memperhatikan rasio leverage perusahaan sehingga menjadikan hubungan leverage dengan pengungkapan CSR menjadi tidak signifikan. Hasil penelitian ini tidak mendukung teori stakeholder yang menyatakan tingkat leverage perusahaan yang tinggi mengakibatkan tingkat resiko tak tertagihnya utang menjadi tinggi pula sehingga kreditor melakukan pengawasan yang ketat terhadap aktivitas perusahaan.

\section{SIMPULAN}

Berdasarkan hasil analisis penelitian yang diperoleh melalui pengujian statistik serta hasil pembahasan pada bab sebelumnya, maka simpulan dari penelitian ini adalah sebagai berikut. Kepemilikan asing berpengaruh positif terhadap pengungkapan Corporate Social Responsibility (CSR). Hal ini menunjukkan bahwa semakin tinggi tingkat kepemilikan asing pada perusahaan, maka upaya pengungkapan corporate social responsibility akan cenderung semakin meningkat. Kepemilikan institusional berpengaruhl positif terhadap pengungkapan Corporate Social Responsibility (CSR). Hal ini menunjukkan bahwa semakin tinggi tingkat kepemilikan institusional pada perusahaan, maka upaya pengungkapan corporate social responsibility akan cenderung semakin meningkat. Leverage secara statistik tidak berpengaruh terhadap pengungkapan Corporate Social Responsibility (CSR). Hal ini menunjukkan bahwa tinggi rendahnya leverage tidak mempengaruhi pengungkapan corporate social responsibility perusahaan. Saranl yang dapat dipergunakan sebagai bahan pertimbangan dalam menentukan kebijakan pengungkapan Corporate Social Responsibility (CSR) pada perusahaan 
pertambangan dimasa mendatang, antara lain: 1) tingkat kepemilikan asing dan institusional perlu ditingkatkan karena akan memiliki dampak signifikan bagi peningkatan pengungkapan Corporate Social Responsibility (CSR) pada perusahaan pertambangan, karena kedua variabel tersebut memiliki hubungan yang signifikan terhadap pengungkapan corporate social responsibility. 2) Nilai adjusted/ $R$ square yang rendah sebesar 39,2 persen menunjukkan bahwa masih terdapat faktor-faktor lainnya yang mempengaruhi pengungkapan corporate social responsibilityi (CSR)i iselain kepemilikani asing,, kepemilikan, institusionall dan, leverage.. 3) Pengungkapan Corporate Social Responsibility (CSR) dalam penelitian ini diproksikan dengan CSRDI (Corporate Social Responsibility Disclosure Index) berdasarkan indikator GRI-G4 yaitu, sebanyak 91 item pengungkapan. Diharapkan item pengungkapan corporate social responsibility perusahaan diperbaharui sehingga dapat disesuaikan dengan kondisi yang terjadi dalam masyarakat.

\section{REFERENSI}

Belkaoui, , A \& Karpik, P, G. (1989). Determinant of the corporate decision to disclose social information. Accounting, Auditing and Accountability Journal, 2(1), 36-51.

Brata, N. T. (2014). The Electability of Women Candidates in The Election o Central Java DPRD in 2014. Jurnal Komunitas, 6(2), 158-165. https://doi.org/10.15294/komunitas.v6i2.3306

Brigham, E., \& Houston, J. F. (2006). Manajemen Keuangan Buku 1 (8th ed.). Jakarta: Erlangga.

Dewi, N. M. L., \& Suputra, I. D. G. D. (2019). Pengaruh Profitabilitas dan Leverage pada Nilai Perusahaan dengan Corporate Social Responsibility Sebagai Variabel Pemoderasi. E-Jumal Akuntansi Universitas Udayana, 28(1), 26-54.

Dewi, N. P. M. S., \& Suaryana, I. G. N. A. (2015). Pengaruh Profitabilitas dan Kepemilikan Asing Pada Pengungkapan Corporate Social Responsibility. EJurnal Akuntansi Universitas Udayana, 13(1), 84-98.

Dwipayadnya, P. A., Wiagustini, N. L. P., \& Purbawangsa, I. B. A. (2015). Kepemilikan Manajerial dan Leverage Sebagai Prediktor Profitabilitas dan Pengungkapan Corporate Social Responsibility. Jurnal Buletin Studi Ekonomi, 20(2), 150-157.

Fajrina, R. (2014). Pengaruh Kinerja Lingkungan,Kepemilikan Manajerial, Kepemilikan Institusional,Manajemen Laba dan Solvabilitas Terhadap Penungkapan Tanggung Jawab Sosial Perusahaan (Studi Empiris PadaPerusahaan Yang Terdaftar di Bursa Efek Indonesia Tahun 2009-2011). Skripsi Universitas Negeri Padang.

Ghozali, I. (2016). Aplikasi Analisis Multivariate dengan Program IMB SPSS 23. (8th ed.). Semarang: Universitas Diponegoro.

Giuliani, E. (2016). Human Rights and Corporate Social Responsibility in Developing Countries' Industrial Clusters. Journal of Business Ethics, 133(1), 39-54. https://doi.org/10.1007/s10551-014-2375-5

Gray, R., Kouhy, R., \& Lavers, S. (1995). Methodological themes Constructing a research database of social and environmental reporting by UK companies. Department of Accounting and Business Finance, University of Dundee, 8(2), 78- 
101.

Hackston, D., \& Milne, M. J. (2009). Some Determinants of social and environmental disclosures in New Zealand companies. University of Otago, Dunedin, New Zealand.

Haniffa, R. M., \& Cooke, T. E. (2005). The impact of culture and governance on corporate social reporting. Journal of Accounting and Public Policy, 24, 391430. https://doi.org/10.1016/j.jaccpubpol.2005.06.001

Ikmal, A. (2014). Analysis Of The Influence Of Good Corporate Governance Structur And Company Characteristics On The Disclosure Of Corporate Social Responsibility In The Sustainability Reports. Universitas Bakrie.

Indraswari, I. G. A. L., \& Mimba, N. P. S. H. (2017). Pengaruh Profitabilitas, Pertumbuhan Perusahaan, Kapitalisasi Pasar dan Kepemilikan Saham Publik Pada Tingkat Pengungkapan CSR. E-Jurnal Akuntansi Universitas Udayana, 20(2), 1219-1248.

Martínez, J. B., Fernández, L. M., \& Fernández, P. M. R. (2016). Corporate Social Responsibility: Evolution Through Institutional and Stakeholder Perspectives. European Journal of Management and Business Economics, 25(1), 8-14. https://doi.org/10.1016/j.redee.2015.11.002

Mathews, M. R. (2014). Social and Environmental Accounting: A Practical Demonstration of Ethical Concern. 14(8), 663-671.

Maulida, D. (2013). Pengaruh Kepemilikan Asing, Afiliasi Asing, dan Proyek Pemerintah Terhadap Luas Pengungkapan Tanggung Jawab Sosial Perusahaan. Skripsi Universitas Diponogoro.

Nugraheni, P., \& Wijayanti, R. (2017). Analysis of Factors Affecting The Disclosure of Islamic Social Reporting (Empirical Studies on The Shariah Compliant Companies in The Sharia Securities List). Journal of Economics, $\begin{array}{lllll}\text { Business } \mathcal{E} \text { Accountancy Ventura, } & 103 .\end{array}$ https://doi.org/10.14414/jebav.v20i1.788

Oktariani, N. W., \& Mimba, N. P. S. H. (2014). Pengaruh Karakteristik Perusahaan Dan Tanggung Jawab Lingkungan Pada Pengungkapan Tanggung Jawab Sosial Perusahaan. E-Jurnal Akuntansi Universitas Udayana, 6(3), 402-418.

Prihatiningtias, Y. W., \& Dayanti, N. (2014). Corporate Social Responsibility Disclosure and Firm Financial Performance in Mining and Natural Resources Industry. The International Journal of Accounting and Business Society, 22(1), 35-59.

Purba, I. B. G. W., \& Yadnya, P. (2015). Pengaruh Ukuran Perusahaan dan Leverage Terhadap Profitabilitas dan Pengungkapan Corporate Social Responsibility. E-Jurnal Manajemen Unud, 4(8), 2428-2443.

Riswari, D. A., \& Cahyonowati, N. (2012). Pengaruh Corporate Social Responsibility Tehadap Nilai Perusahaan Dengan Corporate Governance Sebagai Variabel Moderating : Studi Pada Perusahaan Publik Non Finansial Yang Tercatat Di Bursa Efek Indonesia. Diponegoro Journal of Accounting, 1(1), 1-12.

Sanjaya, O., Taufik, T., \& L, A. A. (2012). Pengaruh Good Corporate Governance, Profitabilitas, dan Ukuran Perusahaan Terhadap Pengungkapan Tanggung Jawab Sosial Perushaan Pada Perusahaan Real Estate dan Property Yang Terdaftar Di 
Bursa Efek Indonesia ( 2010-2011 ). 1-15.

Soliman, M. M., El Din, M. B. El, \& Sakr, A. (2012). Ownership Structure and Corporate Social Responsibility (CSR): An Empirical Study of the Listed Companies in Egypt. SSRN Electronic Journal, 5(1), 63-74. https://doi.org/10.2139/ssrn.2257816

Surmadewi, N. K. Y., \& Suputra, I. D. G. D. (2019). Pengaruh Likuiditas, Leverage , dan Profitabilitas Terhadap Nilai Perusahaan Pada Perusahaan Farmasi. EJurnal Ekonomi Dan Bisnis Universitas Udayana, 8(6), 567-593.

Tan, A., Benni, D., \& Liani, W. (2016). Determinants of Corporate Social Responsibility Disclosure and Investor Reaction. International Journal of Economics and Financial Issues, 6(4), 11-17.

Widyastari, N. K. W., \& Sari, M. M. R. (2018). Pengaruh Ukuran Perusahaan, Proporsi Dewan Komisaris Independen, dan Kepemilikan Asing Pada Pengungkapan Corporate Social Responsibility. E-Jurnal Akuntansi Universitas Udayana, 22(3), 1826-1856.

Yanti, N. K. A. G., \& Budiasih, I. G. A. N. (2016). Pengaruh Profitabilitas, Leverage dan Ukuran Perusahaan Pada Pengungkapan Corporate Social Responsibility. E-Jurnal Akuntansi Universitas Udayana, 17(3), 1752-1779. 